\title{
Geochronology and Hf-Fe isotopic geochemistry of the Phanerozoic mafic-ultramafic intrusions in the Damiao area, northern North China Craton: Implications for lithospheric destruction
}

\author{
JiULONG ZHOU and ZhaOHUA LUO* \\ School of Earth Sciences and Resources, China University of Geosciences, Beijing 100083, China. \\ *Corresponding author.e-mail: cugberbj@hotmail.com
}

\begin{abstract}
Timing and source of several Fe-mineralized mafic-ultramafic intrusions in the Damiao area are investigated here by coupling new geochronological and $\mathrm{Hf}-\mathrm{Fe}$ isotopic data with previous results. Although regarded as a Late Paleoproterozoic assemblage previously, two $\sim 140 \mathrm{Ma}$ intrusions are recognized by zircon $\mathrm{U}-\mathrm{Pb}$ dating, indicating emplacement of these intrusions from Middle Devonian to Early Cretaceous times. Both Hf and Fe isotopic features lead to the conclusion that distinct mantle components contributed to their magma generation. As the first magmatic phase, the $\sim 395$ Ma intrusions were mainly derived from the slightly-enriched SCLM that was prevalent during the Paleozoic. However, asthenospheric material was strongly involved in the formation of the $\sim 215 \mathrm{Ma}$ Gaositai intrusion. Therefore, the initiation of lithospheric destruction in the northern NCC is inferred to have occurred in Late Triassic time, triggered by post-orogenic extension following the $\sim 250$ Ma collision between the Siberian Craton and the NCC. The $\sim 140 \mathrm{Ma}$ intrusions originated from a significantly-enriched mantle component probably resided in the predominant slightly-enriched SCLM. This mantle source would have melted in the Late Mesozoic, when the thin lithosphere enabled enhanced heat transfer from the asthenosphere. In summary, these distinct mantle sources of mafic-ultramafic magmatism provide a record of mantle heterogeneity and the gradual upward migration of the lithosphere-asthenosphere boundary during lithospheric destruction.
\end{abstract}

\section{Introduction}

Cratons are marked by underlying lithospheric mantle keels and thought to be the most stable tectonic units on Earth (Carlson et al. 2005). However, multidisciplinary investigations have unravelled that the North China Craton (NCC) experienced intense Phanerozoic reactivation and its thick subcontinental lithospheric mantle (SCLM) was significantly removed (e.g., Menzies et al. 1993; Xu 2001, 2007; Zhang et al. 2002; Chen et al. 2008, 2009a; Tian et al. 2009; Yan et al. 2010; Dong et al. 2013; Li and Santosh 2013). Exposed Phanerozoic igneous rocks throughout the NCC are dominantly of felsic-intermediate compositions with only minor mafic-ultramafic products, which hinder the reconstruction of deep-level processes. Consequently, several basic issues, such as the initiation timing, duration and dynamic mechanism of the destruction of the NCC, remain open to

Keywords. Mafic-ultramafic rock; mantle source region; Late Mesozoic; lithospheric destruction; Damiao; North China Craton. 
debate (e.g., Wu et al. 2008; Xu et al. 2009, 2013; Zhang 2012; Zhu et al. 2012a, b; Ling et al. 2013; Zhang et al. 2013).

The Damiao area is well-known in China for its unique Proterozoic massif-type anorthosite, the Damiao anorthosite complex (Xie 2005). Besides this, several mafic-ultramafic intrusions (pyroxenite-hornblendite complexes) are also distributed around or within the anorthosite complex. Owing to their imprecise $\mathrm{K}-\mathrm{Ar}$ ages, location within the Trans-North China Orogen and spatial relationship with the massif-type anorthosite complex, these intrusions were previously regarded as a Late Paleoproterozoic post-orogenic assemblage (e.g., Bai et al. 1993; Trap et al. 2011). But it has been indicated recently that some of them are instead Phanerozoic in age (Zhang et al. 2009a; Zhou et al. 2012; Li et al. 2012a, b). The maficultramafic rocks in the Damiao area, as the direct magmatic expression of deep-level processes, therefore give a chance to understand the destruction of the NCC.

In this contribution, we present new $\mathrm{U}-\mathrm{Pb}$ geochronological and Hf-Fe isotopic data, and integrate the previous data to discuss the timing and source region of the mafic-ultramafic magmatism in the Damiao area. Based on this, the lithospheric destruction process beneath the northern NCC is further constrained.

\section{Geological setting}

The northern NCC was traditionally thought to be a passive continental margin, but many researchers argue that it was intensely modified during the tectonic evolution of the Paleoasian Ocean (e.g., Zhang et al. 2009a, b, c, 2012; Wang et al. 2011; Ma et al. 2013). The Damiao area is situated on the north-central margin of the NCC, approximately $25 \mathrm{~km}$ north of Chengde, Hebei Province (figure 1a). It straddles the EW-trending JiningLonghua fracture zone (a long-lived large-scale deep structure; HBGMR 1989), which separates the Inner Mongolia paleouplift in the north from the Yanshan fold-and-thrust belt in the south (Zhang et al. 2009c; Wang et al. 2011).

The basement rocks in the Damiao area are mainly composed of Neoarchean to Paleoproterozoic TTG gneisses with minor mafic granulites and amphibolites. They are unconformably overlain by Meso-Neoproterozoic, Cambrian-Ordovician, Carboniferous-Triassic, Jurassic-Cretaceous and younger unmetamorphosed strata. The Damiao anorthosite complex intruded into the Precambrian metamorphic country rocks, with an exposed area of $\sim 80 \mathrm{~km}^{2}$ (figure $1 \mathrm{~b}$ ). U-Pb isotope systematics of zircon record an emplacement age of
$1739 \pm 14 \mathrm{Ma}$ (Zhao et al. 2009). Together with the Miyun rapakivi granite, it partly comprises an anorthosite-mangerite-charnockite-granite suite in the $\sim 1.85 \mathrm{Ga}$ Trans-North China Orogen (Zhang et al. 2007; Zhao et al. 2009).

There are three mafic-ultramafic intrusions exposed around the Damiao anorthosite complex: The Xiahabaqin, Gaositai, and Longwangmiao intrusions. In addition, a mafic-ultramafic intrusion beneath Dawusugou was recently discovered by drilling (named Dawusugou intrusion in this paper) and a mafic-ultramafic dyke has been newly recognized near Daheishan as a result of this work (named Heishan intrusion in this paper).

\section{Occurrence, petrography and mineralization}

These mafic-ultramafic intrusions occur near the branches of the EW-trending JiningLonghua fracture zone. They are characterized by small, elliptical or rounded, and crudely concentrically zoned occurrence. Only the Gaositai intrusion displays a complete transitional sequence of zoning with dunite in the core, mantled by pyroxenite and rimed by hornblendite; other bodies consist of pyroxenite and/or hornblendite. Mineralogically, these rock types primarily consist of olivine, pyroxene, and hornblende with minor biotite and rare plagioclase as rock-forming minerals (figure 2). In addition to chalcopyrite and titanite, zircon is also associated as accessory mineral (figure 2e), which has been reported for other maficultramafic rocks (e.g., Malitch et al. 2010; Su et al. 2011; Su and Lesher 2012; Kwon et al. 2013). Secondary minerals mainly include calcite, epidote and serpentine. In general, these intrusions share many similarities with Alaskan/Ural-type intrusions, for which the mineralization is dominated by $\mathrm{Fe}-\mathrm{Ti}$ oxides and platinum group minerals (Taylor and Noble 1969; Himmelberg and Loney 1995).

In fact, the pyroxenite and hornblendite in these intrusions are Fe-mineralized extensively with a disseminated style. As shown in figure 2, rockforming minerals (pyroxene, hornblende and minor biotite) are subhedral to euhedral in morphology, while $\mathrm{Fe}-\mathrm{Ti}$ oxides are commonly anhedral and occur as interstitial grains. However, there are also some euhedral $\mathrm{Fe}-\mathrm{Ti}$ oxides enclosed by pyroxene oikocrysts, suggesting a prolonged crystallization history for $\mathrm{Fe}-\mathrm{Ti}$ oxides. The textures of $\mathrm{Fe}-\mathrm{Ti}$ oxides are consistent with their magmatic origin. Apatite and $\mathrm{Fe}-\mathrm{Ti}$ oxides are always closely associated. The $\mathrm{Fe}_{2} \mathrm{O}_{3}^{\mathrm{t}}$ content of mineralized samples from these mafic-ultramafic 

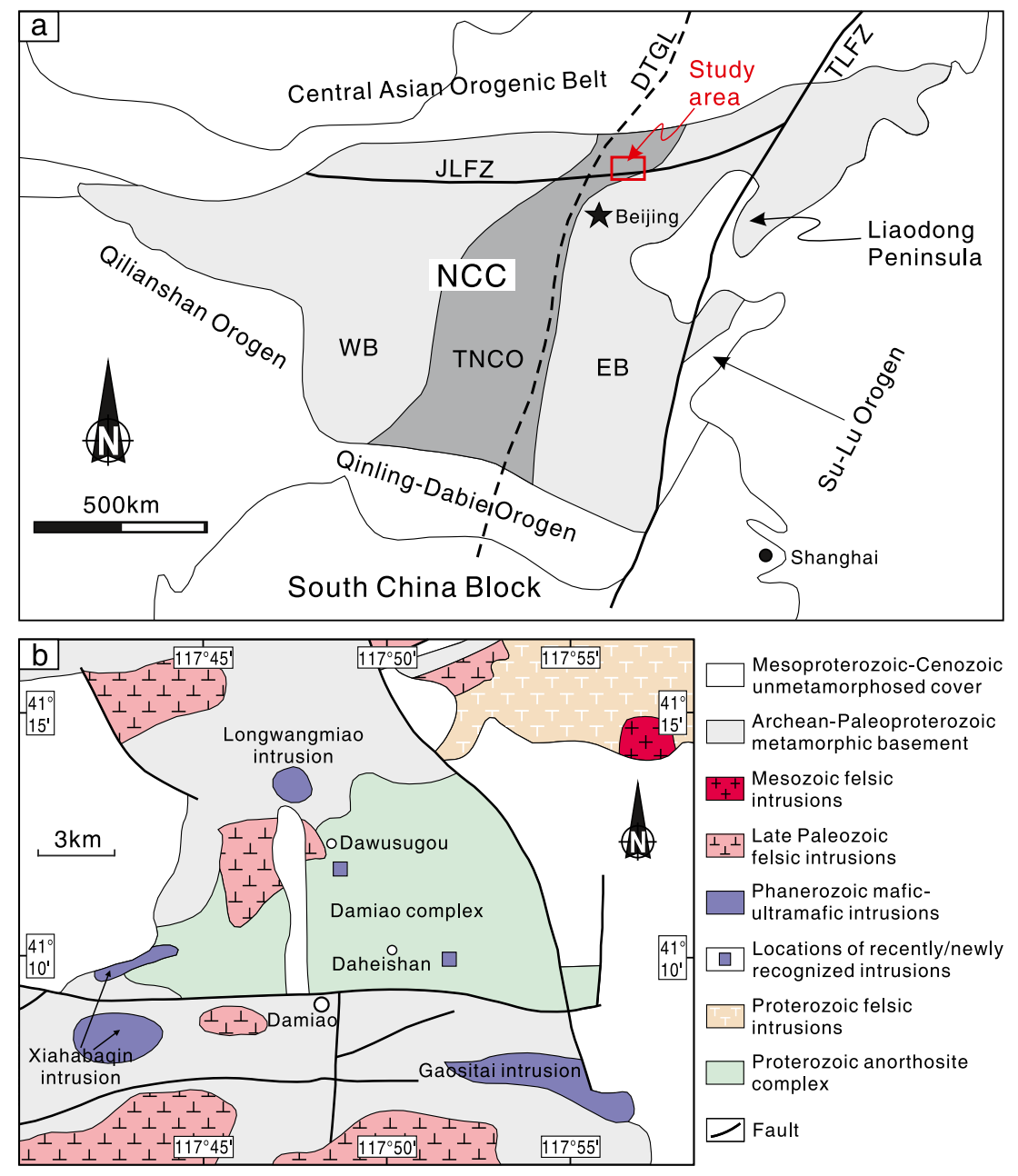

Figure 1. (a) Tectonic sketch map of China with location of the study area (modified after Zheng et al. 2013) and (b) simplified geological map of the Damiao area, showing distribution of the Phanerozoic mafic-ultramafic intrusions around or within the Proterozoic anorthosite complex (modified after Zhang et al. 2007). In (a), WB: Western Block; EB: Eastern Block; TNCO: Trans-North China Orogen; JLFZ: Jining-Longhua fracture zone; TLFZ: Tan-Lu fracture zone; DTGL: Daxing'anling-Taihangshan gravity lineament.

intrusions varies from 13 to $35 \%$, with an average of $16.5 \%$ (Xie et al. 2006). Owing to the imbalance of supply and demand of iron ores, this disseminated type of $\mathrm{Fe}$ mineralization is actually economical in north-central China, with a minable grade of $\sim 15 \%$ (Li et al. 2009a; Xie et al. 2009).

\section{Samples and analytical methods}

To enable systematic discussion, complementary analyses have been conducted for these maficultramafic intrusions. Firstly, U-Pb ages (table 1) and Hf isotopic data (table 2) are reported on zircons in sample LWM-3 (Fe-mineralized pyroxenite) from the Longwangmiao intrusion and sample HS-3 (Fe-mineralized hornblendite) from the
Heishan intrusion. Secondly, Fe isotopic data (table 3) are acquired on 17 fresh samples (Femineralized pyroxenite/hornblendite) from four intrusions to better constrain the magma source. The newly-obtained ages and $\mathrm{Hf}-\mathrm{Fe}$ isotopes, together with the previous results, are then summarized in table 4.

\section{$4.1 \mathrm{U}-\mathrm{Pb}$ dating}

Zircons were extracted using standard crushing and separation techniques. After being handpicked under a binocular microscope, zircon grains without cracks were then set in a resin mount and polished down to about half their size. In order to observe internal textures, cathodoluminescence (CL) imaging was conducted for the 

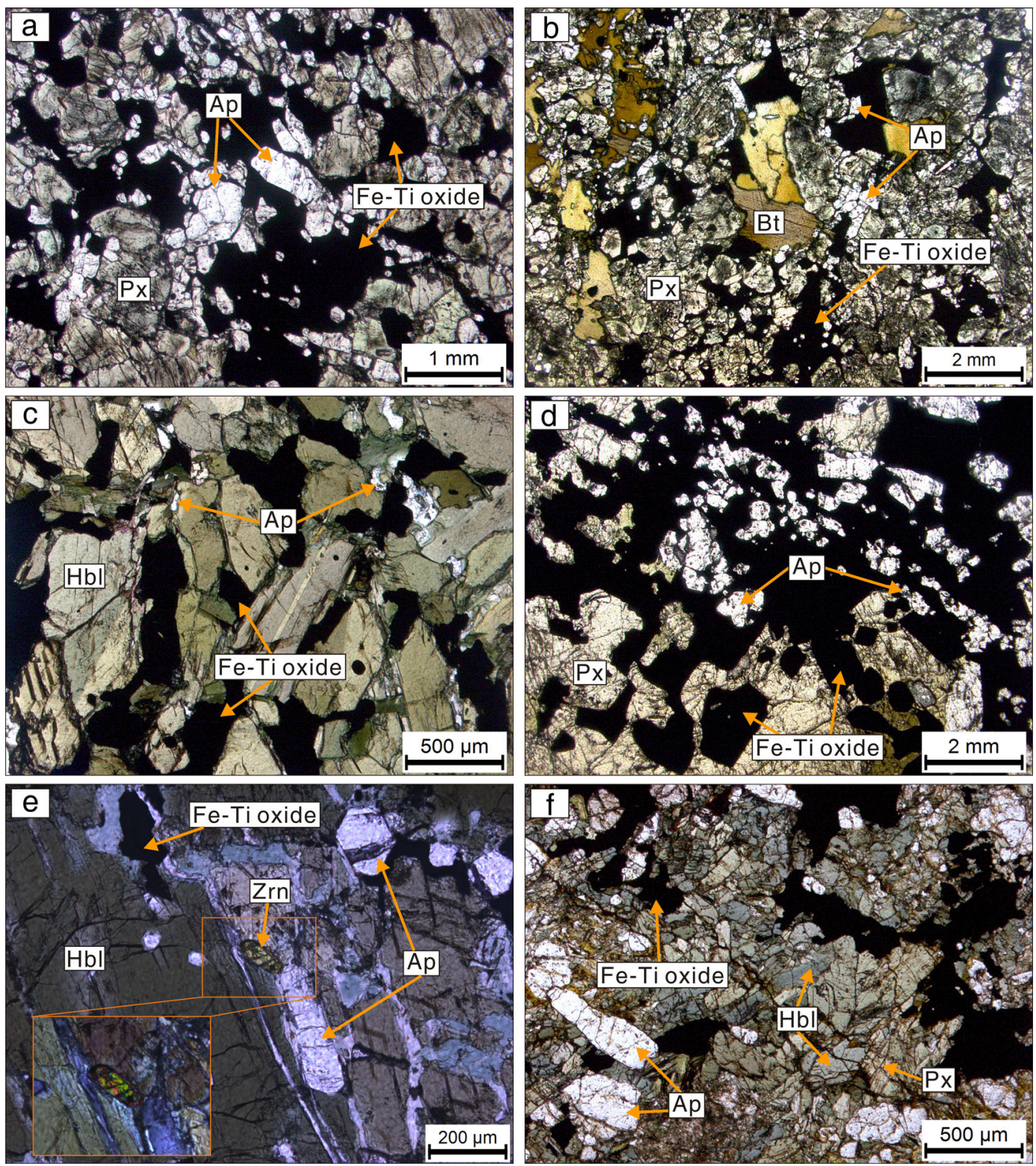

Figure 2. Photomicrographs illustrating the petrographic and mineralization characteristics of the Phanerozoic maficultramafic intrusions in the Damiao area. (a) and (b) Fe-mineralized pyroxenite and biotite-bearing pyroxenite from the Dawusugou intrusion; (c) Fe-mineralized hornblendite from the Gaositai intrusion; (d) and (e) Fe-mineralized pyroxenite and hornblendite from the Longwangmiao intrusion, showing zircon associated with host rock; (f) Fe-mineralized hornblendite from the Heishan intrusion. Except the inset in (e) taken under cross-polarized light, the other photomicrographs were taken under plane-polarized light. Mineral abbreviations: Px: pyroxene; Hbl: hornblende; Bt: biotite; Ap: apatite; Zrn: zircon.

zircons prior to in-situ $\mathrm{U}-\mathrm{Pb}$ dating and $\mathrm{Hf}$ isotope analysis.

In-situ $\mathrm{U}-\mathrm{Pb}$ dating was carried out by an Agilent 7500a ICP-MS coupled with a GeoLas 200M laser-ablation system at the State Key Laboratory of Continental Dynamics, Northwest University, China. A beam diameter of $30 \mu \mathrm{m}$ was chosen for sampling. Detailed analytical procedures are similar to those reported by Liu et al. (2007). Standard zircon 91500 was used for calibration, and raw data reduction and calculation were processed with the program GLITTER4.4 (Griffin et al. 2008). The method designed by Andersen (2002) was applied for common $\mathrm{Pb}$ correction. The results were finally plotted by the program Isoplot3.0 (Ludwig 2003).

\subsection{Hf isotope analysis}

In-situ $\mathrm{Hf}$ isotope analysis was carried out by a $\mathrm{Nu}$ Plasma HR MC-ICP-MS equipped with a GeoLas 


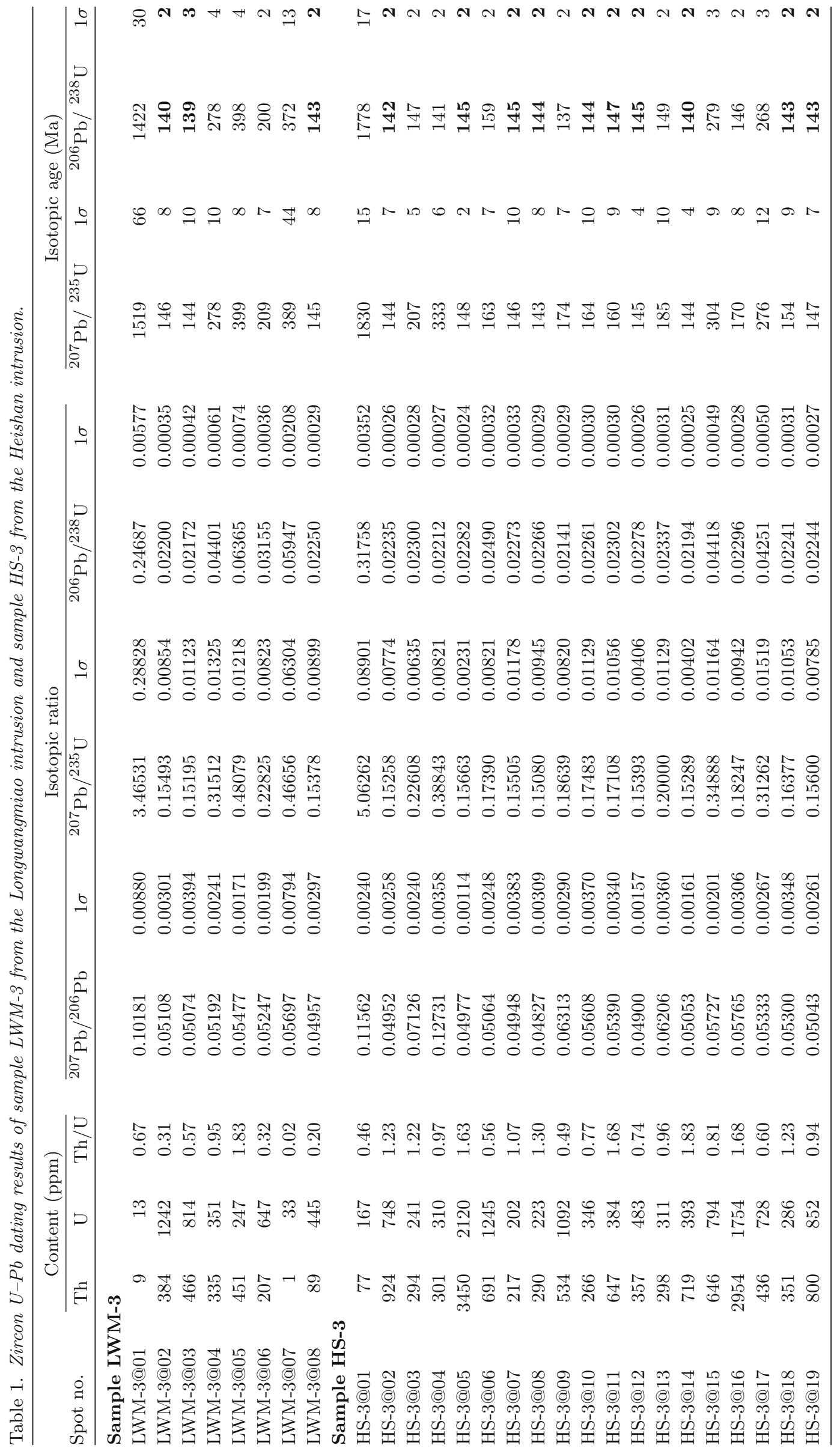




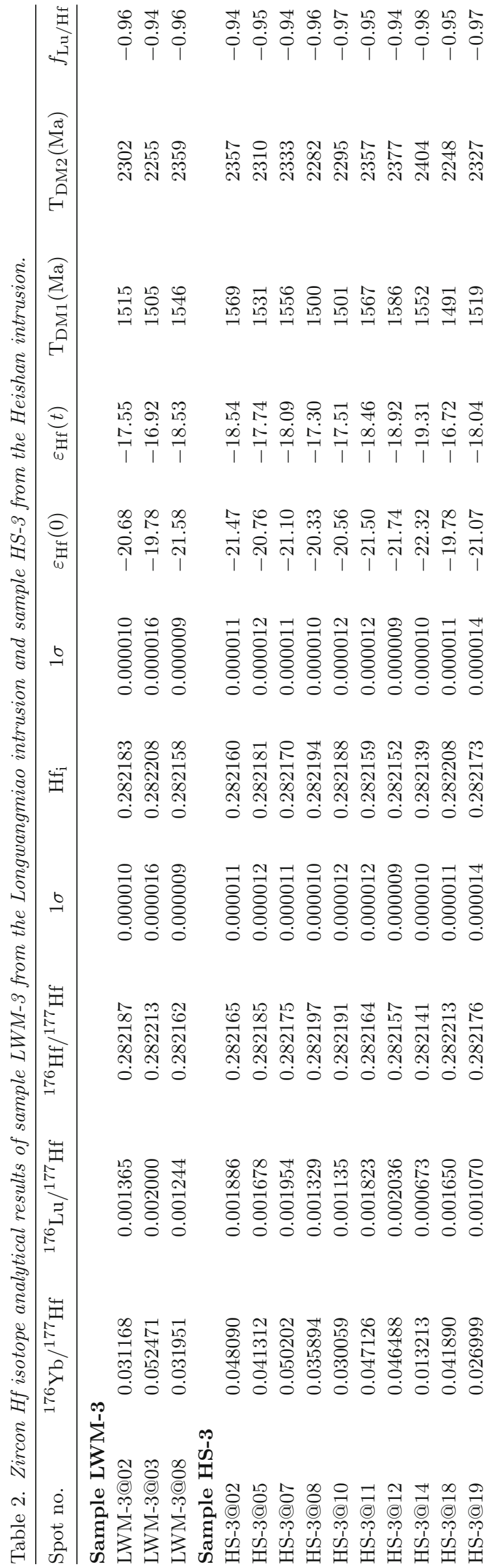

2005 laser-ablation system at the State Key Laboratory of Continental Dynamics, Northwest University, China. A spot size of $40 \mu \mathrm{m}$ was selected for sampling. Detailed analytical procedures have been outlined in Yuan et al. (2008). Standard zircon 91500 was used for the correction of mass fractionation, time-dependent drift, and interference of ${ }^{176} \mathrm{Yb}$ and ${ }^{176} \mathrm{Lu}$. Initial ${ }^{176} \mathrm{Hf} /{ }^{177} \mathrm{Hf}$ ratios and $\varepsilon_{\mathrm{Hf}}(t)$ values were calculated based on the ${ }^{176} \mathrm{Lu}$ decay constant of $1.867 \times 10^{-11} \mathrm{yr}^{-1}$ (Söderlund et al. 2004) and chondritic ratios of ${ }^{176} \mathrm{Hf} /{ }^{177} \mathrm{Hf}$ $(=0.282772)$ and ${ }^{176} \mathrm{Lu} /{ }^{177} \mathrm{Hf}(=0.0332)$ proposed by Blichert-Toft and Albarède (1997). Present-day ratios of ${ }^{176} \mathrm{Hf} /{ }^{177} \mathrm{Hf}(=0.28325)$ and ${ }^{176} \mathrm{Lu} /{ }^{177} \mathrm{Hf}$ $(=0.0384)$ reported by Griffin et al. (2000) were adopted for the depleted mantle to calculate singlestage model ages $\left(\mathrm{T}_{\mathrm{DM} 1}\right)$. Two-stage model ages $\left(\mathrm{T}_{\mathrm{DM} 2}\right)$ were also calculated by assuming the average continental crust with a ${ }^{176} \mathrm{Lu} /{ }^{177} \mathrm{Hf}$ ratio of 0.015 (Griffin et al. 2002).

\subsection{Fe isotope analysis}

Bulk samples for Fe isotope analysis were crushed to less than 200 mesh, digested by concentrated HF and $\mathrm{HNO}_{3}$ mixture, and then evaporated to dryness. In order to convert the cations to chlorideform, the residues were repeatedly treated with concentrated $\mathrm{HCl}$. Subsequently anion exchange chromatography was adopted for Fe separation and purification following Tang et al. (2006).

$\mathrm{Fe}$ isotopic ratios were determined at the Laboratory of Isotopic Geology, Institute of Geology, Chinese Academy of Geological Sciences using a Nu Plasma HR MC-ICP-MS in high-resolution mode. Signal of ${ }^{53} \mathrm{Cr}$ was collected simultaneously with the $\mathrm{Fe}$ isotopes as an interference monitor. The standard-sample bracketing technique was used for correction of instrumental mass bias. Detailed analytical and calibration procedures have been presented by Zhu et al. (2008). Finally, Fe isotopic results are expressed in $\delta$ notation relative to reference material IRMM-014:

$$
\begin{aligned}
& \delta^{56} \mathrm{Fe}_{\mathrm{IRMM}-014}(\% 0)=\left[\frac{\left(\frac{56 \mathrm{Fe}}{54 \mathrm{Fe}}\right)_{\text {sample }}}{\left(\frac{56 \mathrm{Fe}}{54 \mathrm{Fe}}\right)_{\mathrm{IRMM}-014}}-1\right] \times 10^{3} ; \\
& \delta^{57} \mathrm{Fe}_{\mathrm{IRMM}-014}(\%)=\left[\frac{\left(\frac{57 \mathrm{Fe}}{54 \mathrm{Fe}}\right)_{\text {sample }}}{\left(\frac{57 \mathrm{Fe}}{54 \mathrm{Fe}}\right)_{\mathrm{IRMM}-014}}-1\right] \times 10^{3} .
\end{aligned}
$$

Long-term reproducibility in high-resolution mode is better than $0.10 \% 0(2 \sigma)$ for $\delta^{57} \mathrm{Fe}$, and $0.08 \% 0(2 \sigma)$ for $\delta^{56} \mathrm{Fe}$ based on repeated determinations of national basaltic reference material CAGSR-1. 
Table 3. Fe isotope analytical results of the Phanerozoic mafic-ultramafic intrusions in the Damiao area.

\begin{tabular}{|c|c|c|c|c|}
\hline Intrusions & Sample no. & Description & $\delta^{57} \mathrm{Fe}(\% 0)$ & $\delta^{56} \mathrm{Fe}(\%)$ \\
\hline \multirow[t]{5}{*}{ Dawusugou } & WSG-2 & Fe-mineralized pyroxenite & 0.27 & 0.16 \\
\hline & WSG-4 & Fe-mineralized pyroxenite & 0.20 & 0.09 \\
\hline & WSG-5 & Fe-mineralized pyroxenite & 0.10 & 0.03 \\
\hline & WSG-7 & Fe-mineralized pyroxenite & 0.12 & 0.06 \\
\hline & WSG-8 & Fe-mineralized pyroxenite & 0.28 & 0.18 \\
\hline \multirow[t]{6}{*}{ Gaositai } & GST-1 & Fe-mineralized pyroxenite & 0.03 & 0.01 \\
\hline & GST-3 & Fe-mineralized pyroxenite & 0.17 & 0.12 \\
\hline & GST-4 & Fe-mineralized pyroxenite & 0.03 & -0.01 \\
\hline & GST-7 & Fe-mineralized hornblendite & 0.04 & 0.04 \\
\hline & GST-9 & Fe-mineralized hornblendite & 0.24 & 0.17 \\
\hline & GST-12 & Fe-mineralized hornblendite & 0.22 & 0.15 \\
\hline \multirow[t]{4}{*}{ Longwangmiao } & LWM-3 & Fe-mineralized pyroxenite & 0.33 & 0.20 \\
\hline & LWM-4 & Fe-mineralized pyroxenite & 0.26 & 0.15 \\
\hline & LWM-5 & Fe-mineralized pyroxenite & 0.38 & 0.20 \\
\hline & LWM-9 & Fe-mineralized hornblendite & 0.41 & 0.26 \\
\hline \multirow[t]{2}{*}{ Heishan } & HS-3 & Fe-mineralized hornblendite & 0.32 & 0.22 \\
\hline & HS-4 & Fe-mineralized hornblendite & 0.37 & 0.24 \\
\hline
\end{tabular}

Table 4. Summary of ages and Hf-Fe isotopes of the Phanerozoic mafic-ultramafic intrusions in the Damiao area.

\begin{tabular}{llcccl}
\hline Intrusion & \multicolumn{1}{c}{ Dating method } & Age $(\mathrm{Ma})$ & $\varepsilon_{\mathrm{Hf}}(t)$ & $\delta^{57} \mathrm{Fe}(\%)$ & Data source \\
\hline Xiahabaqin & Zircon SHRIMP U-Pb & $392 \pm 5$ & $-8.01 \pm 0.75$ & No data & Zhang et al. $(2009 \mathrm{a}) ;$ Li et al. $(2012 \mathrm{~b})$ \\
& Hornblende ${ }^{40} \mathrm{Ar} /{ }^{39} \mathrm{Ar}$ & $401 \pm 8$ & & & \\
Dawusugou & Biotite ${ }^{40} \mathrm{Ar} /{ }^{39} \mathrm{Ar}$ & $396 \pm 4$ & No data & $0.19 \pm 0.10$ & Zhou et al. $(2012) ;$ this study \\
Gaositai & Zircon LA-ICP-MS U-Pb & $213 \pm 1$ & $-0.23 \pm 0.70$ & $0.12 \pm 0.10$ & Li et al. $(2012 \mathrm{a}) ;$ this study \\
Longwangmiao & Zircon LA-ICP-MS U-Pb & $141 \pm 3$ & $-17.90 \pm 1.90$ & $0.34 \pm 0.10$ & This study \\
Heishan & Zircon LA-ICP-MS U-Pb & $144 \pm 1$ & $-18.12 \pm 0.59$ & $0.35 \pm 0.07$ & This study \\
\hline
\end{tabular}

\section{Results}

\subsection{Zircon $U-P b$ ages}

CL images of representative zircons are displayed in figure 3 . The results of zircon $\mathrm{U}-\mathrm{Pb}$ dating are listed in table 1 and plotted on concordia diagrams in figure 4. Only a few grains of zircon were separated from sample LWM-3, and they are mostly transparent and 100-200 $\mu \mathrm{m}$ in size. In CL images, they show oscillatory zoning with occasional homogeneous luminescence (figure 3a). Eight analyses were made on eight zircon grains, with the $\mathrm{Th} / \mathrm{U}$ ratios ranging from 0.02 to 1.83 (average $=0.61$ ). Their growth zoning and $\mathrm{Th} / \mathrm{U}$ ratios are consistent with a magmatic origin. Consisting of inherited zircons, these analyses have ${ }^{206} \mathrm{~Pb} /{ }^{238} \mathrm{U}$ ages varying from 139 to 1422 Ma. As the upper limit, three youngest concordant data $(02,03,08)$ yielded a weighted mean ${ }^{206} \mathrm{~Pb} /{ }^{238} \mathrm{U}$ age of $141.0 \pm 2.5 \mathrm{Ma}(2 \sigma$, $\mathrm{MSWD}=0.99$ ) (figure $4 \mathrm{a}$ ). Since no younger mafic-ultramafic intrusions have been identified in the northern NCC, we interpret $141 \pm 3 \mathrm{Ma}$ as the emplacement age of the Longwangmiao intrusion.
Zircons in sample HS-3 are mostly transparent and $80-180 \mu \mathrm{m}$ in size. Oscillatory zoning is welldeveloped for most zircons, suggesting a magmatic origin (figure $3 \mathrm{~b}$ ). Nineteen analyses were made on 17 zircon grains, with Th/U ratios from 0.46 to 1.83 (average $=1.07$ ). Except for three inherited ages and six discordant ages, the remaining 10 analyses yielded a weighted mean ${ }^{206} \mathrm{~Pb} /{ }^{238} \mathrm{U}$ age of $143.8 \pm$ $1.2 \mathrm{Ma}(2 \sigma, \mathrm{MSWD}=0.93)$ (figure $4 \mathrm{~b})$. Therefore, the emplacement age of the Heishan intrusion is considered to be $144 \pm 1$ Ma.

\section{$5.2 \mathrm{Hf}$ isotopic data}

Hf isotopic analysis was made on the zircons with a concordant age of $\sim 140 \mathrm{Ma}$, including three spots for sample LWM-3, and 10 spots for sample HS-3. The results are listed in table 2. Zircons in sample LWM-3 have $\varepsilon_{\mathrm{Hf}}(t)$ values from -16.92 to -18.53 , yielding an average of $-17.90 \pm$ $1.90(2 \sigma)$. Similarly, zircons in sample HS-3 show a range of $\varepsilon_{\mathrm{Hf}}(t)$ values from -16.72 to -19.31 , with an average of $-18.12 \pm 0.59(2 \sigma)$. As shown in table 4 , the average $\varepsilon_{\mathrm{Hf}}(t)$ values for the $\sim 140 \mathrm{Ma}$ Longwangmiao and Heishan intrusions are notably 

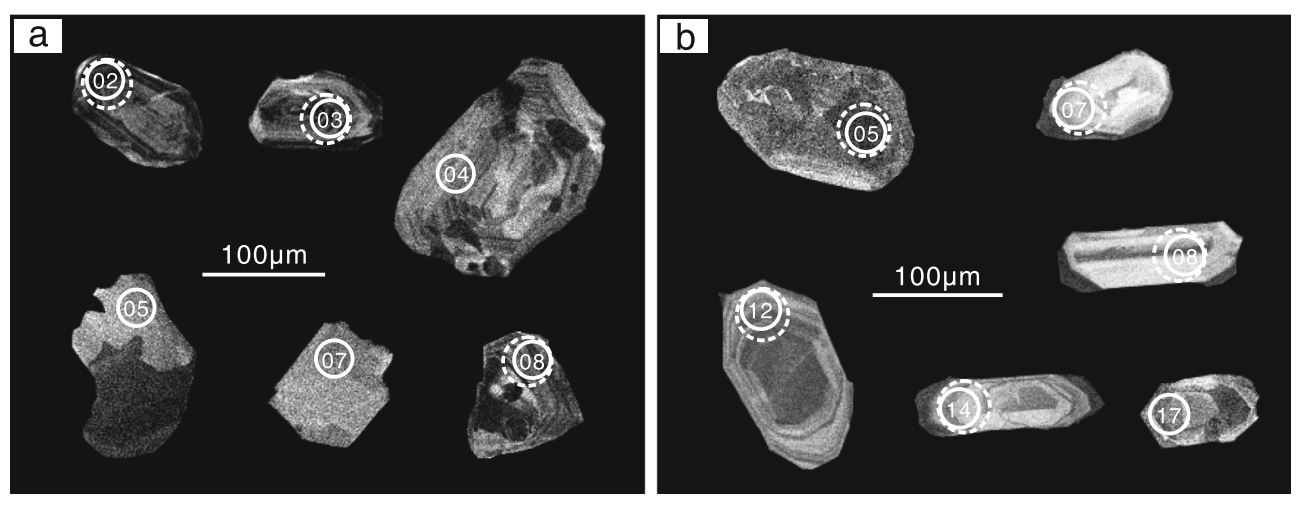

Figure 3. CL images of representative zircons in (a) sample LWM-3 from the Longwangmiao intrusion and (b) sample HS-3 from the Heishan intrusion.
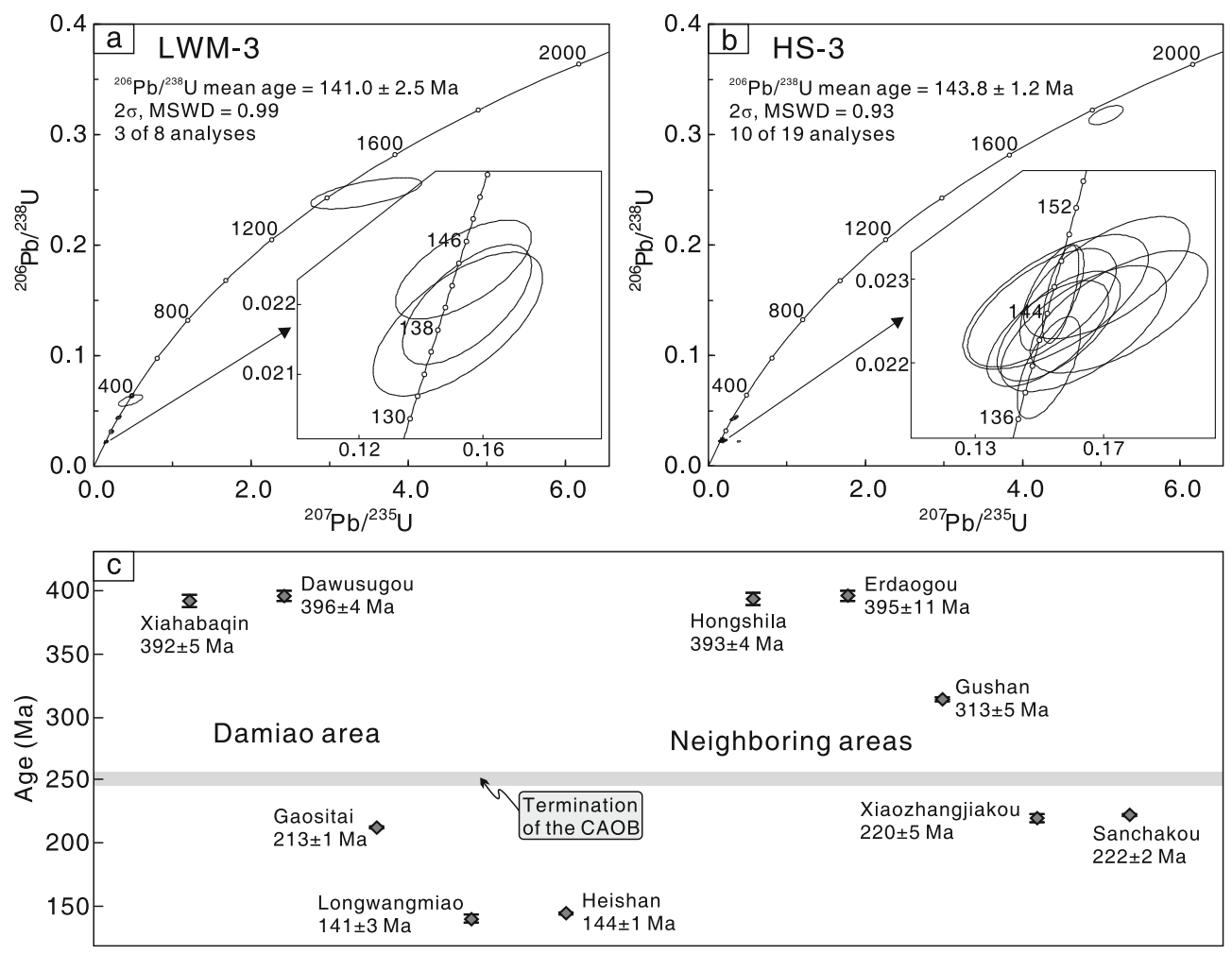

Figure 4. (a) and (b) U-Pb concordia diagrams for zircons in sample LWM-3 from the Longwangmiao intrusion and sample HS-3 from the Heishan intrusion, respectively; (c) chronogram of Phanerozoic mafic-ultramafic magmatic events in the Damiao and neighbouring areas. Data for the Damiao area are after table 4; data for the neighbouring areas are from Tian et al. (2007), Zhang et al. (2009a), Yang et al. (2012), and the authors unpublished data. CAOB: Central Asian orogenic belt. Error ellipses are at $2 \sigma$ level.

lower than those for the $\sim 215$ Ma Gaositai intrusion $(-0.23 \pm 0.70$; recalculated from the data of $\mathrm{Li}$ et al. 2012a) and the $\sim 395$ Ma Xiahabaqin intrusion $(-8.01 \pm 0.75$; recalculated from the data of Zhang et al. 2009a). The single-stage model ages $\left(\mathrm{T}_{\mathrm{DM} 1}\right)$ are of 1505-1546 Ma for sample LWM3 and of 1491-1586 Ma for sample HS-3. The two-stage model ages $\left(\mathrm{T}_{\mathrm{DM} 2}\right)$ were further calculated, varying from 2255 to 2359 Ma for sample LWM-3 and from 2248 to 2404 Ma for sample HS-3.

\subsection{Fe isotopic data}

The 17 analyzed bulk samples were collected from the Dawusugou, Gaositai, Longwangmiao and Heishan intrusions. Their $\delta^{57} \mathrm{Fe}$ values are of $0.03-0.41 \%$, falling within the range of igneous basalts compiled by Zhao et al. (2010). The samples from the $\sim 395$ Ma Dawusugou intrusion have $\delta^{57} \mathrm{Fe}$ values from 0.10 to $0.28 \%$, defining an average of $0.19 \pm 0.10 \%(2 \sigma)$. The samples from the $\sim 215$ Ma Gaositai intrusion show $\delta^{57} \mathrm{Fe}$ values 
ranging from 0.03 to $0.24 \%$, with an average of $0.12 \pm 0.10 \%$ o $(2 \sigma)$. However, the samples from the $\sim 140 \mathrm{Ma}$ Longwangmiao and Heishan intrusions have $\delta^{57} \mathrm{Fe}$ values clearly heavier than the other two bodies, varying from 0.26 to $0.41 \%$ with an average of $0.34 \pm 0.10 \%(2 \sigma)$ and from 0.32 to $0.37 \%$ with an average of $0.35 \pm 0.07 \%$ o $(2 \sigma)$, respectively.

\section{Discussion}

\subsection{Timing and mantle source of magmatism}

Timing and source characteristics of maficultramafic magmatism are crucially important for understanding mantle composition and processes. Based on published geochronological data and the newly-obtained zircon $\mathrm{U}-\mathrm{Pb}$ ages (table 4), the mafic-ultramafic rocks in the Damiao area are known to have formed in the Middle Devonian, Late Triassic and Early Cretaceous ages.

Despite the presence of inherited zircons, the fact that all these intrusions show a limited variation of zircon $\varepsilon_{\mathrm{Hf}}(t)$ values, tends to indicate that crustal contamination during magma ascent may be negligible (figure 5). Thus, their Hf isotopic features are primarily inherited from mantle sources. As a nontraditional stable isotope, $\mathrm{Fe}$ is an effective tracer for identifying the input of enriched lithospheric mantle from crustal contamination. It is because the Fe isotopic signal of continental crust is similar to that of the magma derived from the depleted mantle source, while the Fe isotopic compositions of enriched lithospheric mantle would be modified by mantle metasomatism (figure 6; e.g., Poitrasson 2006; Weyer and Ionov 2007).

\subsubsection{Middle Devonian}

The emplacement age of the Dawusugou intrusion, as revealed by biotite ${ }^{40} \mathrm{Ar} /{ }^{39} \mathrm{Ar}$ dating, indicates that it is contemporaneous with the Xiahabaqin intrusion at $\sim 395 \mathrm{Ma}$, but distinctly younger than the overlying Damiao anorthosite complex (Zhou et al. 2012).

The Xiahabaqin intrusion has a relatively wide range of zircon $\varepsilon_{\mathrm{Hf}}(t)$ values from -11.59 to -4.17 (average $=-8.01$; recalculated from the data of Zhang et al. 2009a). Nonetheless, the zircon $\varepsilon_{\mathrm{Hf}}(t)$ values are still plotted on the inferred evolution line of the SCLM beneath the northern NCC, implying limited contributions from ancient crustal material and its origination from the slightly-enriched SCLM that was prevalent during Paleozoic time (figure 5). Correspondingly, the contemporaneous Dawusugou intrusion displays $\delta^{57} \mathrm{Fe}$ values that are a little higher than average for data from depleted mantle-derived magma (figure 6). This is consistent with its origination from a slightly-enriched mantle

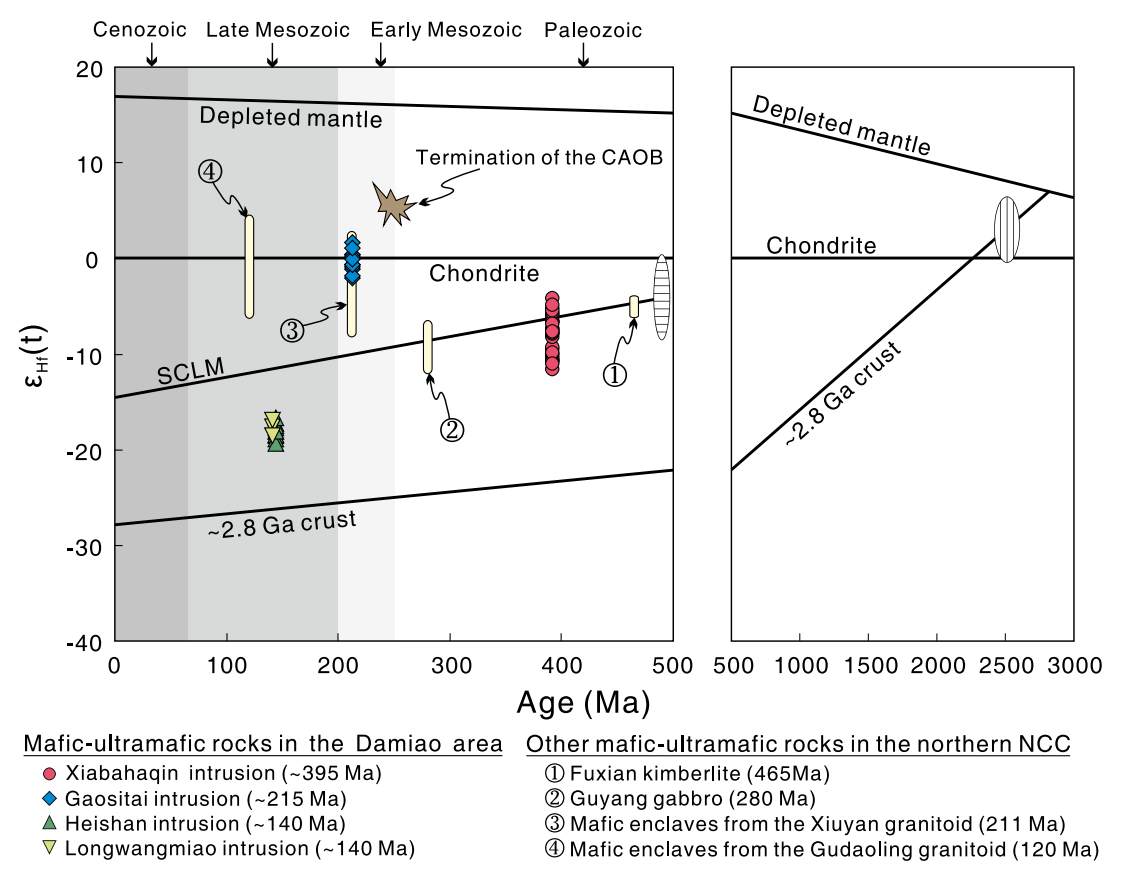

Figure 5. Age-corrected $\varepsilon_{\mathrm{Hf}}(t)$ vs. age diagram. Data of the mafic-ultramafic rocks in the Damiao area are from Zhang et al. (2009a), Li et al. (2012a) and this study. Data of other mafic-ultramafic rocks in the northern NCC are from Zhang and Yang (2007), Yang et al. (2007a, b) and Zhang et al. (2011). The evolution line of the SCLM beneath the northern NCC is inferred by the data of $\sim 490$ Ma mantle zircons entrained in the Xiaozhangjiakou intrusion (elliptical zone with horizontal lines; Tian et al. 2007). The evolution line of the average crust of the northern NCC is inferred by the data of zircons from the Archean TTGs and terrain gneisses (elliptical zone with vertical lines; Yang et al. 2005). 


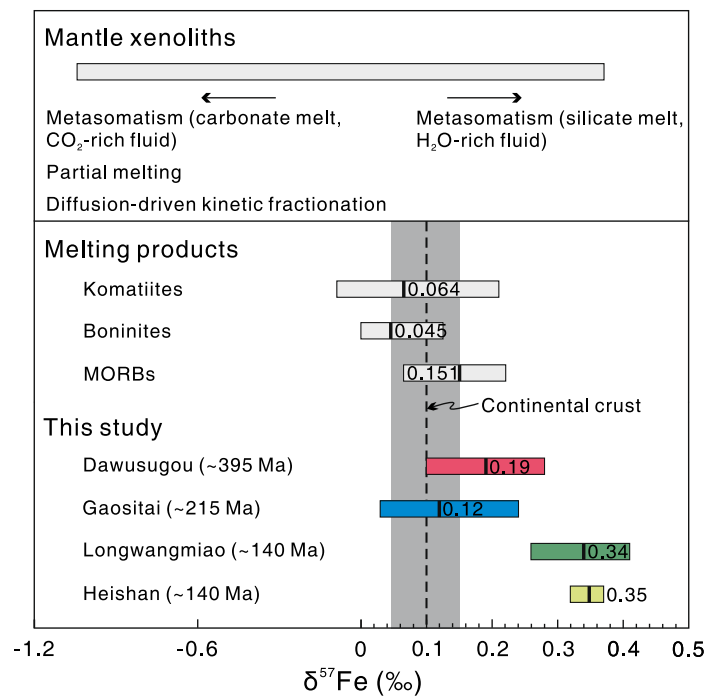

Figure 6. Correlation diagram of $\delta^{57} \mathrm{Fe}$ of the Phanerozoic mafic-ultramafic intrusions in the Damiao area. Data of mantle xenoliths and melting products are compiled by Zhao et al. (2010) with additional data from Dauphas et al. (2009, 2010), Huang et al. (2011), Zhao et al. (2012), Poitrasson et al. (2013) and Teng et al. (2013). The dark grey zone represents the main variation range of $\delta^{57} \mathrm{Fe}$ of komatiites, boninites and MORBs, which are formed by various degree partial melting of depleted mantle source. The vertical dashed line represents the Fe isotopic composition of continental crust $\left(\delta^{57} \mathrm{Fe}=0.10 \pm 0.03\right.$; Poitrasson 2006).

reservoir, for which Fe isotopic compositions would be weakly elevated by mantle metasomatism. Combining the Hf and Fe isotopic features, it is concluded that the Middle Devonian mafic-ultramafic intrusions are the melting products of the prevalent SCLM beneath the northern NCC with slight crustal contamination.

\subsubsection{Late Triassic}

The zircon $\mathrm{U}-\mathrm{Pb}$ age $(280 \pm 3 \mathrm{Ma})$ of the Gaositai intrusion was first reported by Chen et al. (2009b). But as revealed by the results of Zhang et al. (2009a), this weighted mean age is just a reflection of inherited zircons (Luo et al. 2013), which also occur in samples LWM-3 and HS-3 (table 1). Although no reliable crystallization age had been yielded, an upper limit of $265 \mathrm{Ma}$ was given by Zhang et al. (2009a). A subsequent geochronological investigation showed a convincing emplacement age of $213 \pm 1 \mathrm{Ma}$ ( $\mathrm{Li}$ et al. 2012a). As mentioned above, the Gaositai intrusion shares many typically geological and petrographic features with Alaskan/Ural-type intrusions, which are regarded as the hallmarks of arc magmatism (Himmelberg and Loney 1995; Pettigrew and Hattori 2006; Tseng et al. 2009). However, it is noteworthy that the $\sim 215$ Ma emplacement age postdates the final closure of the Paleoasian Ocean $(\sim 250 \mathrm{Ma}$; Xiao et al. 2003; Zhang et al. 2009c). Thus, the tectonic indication of Alaskan/Ural-type intrusions is still controversial.

A narrow range from -2.02 to 1.63 (average $=$ $-0.23)$ is exhibited for the zircon $\varepsilon_{\mathrm{Hf}}(t)$ values of the Gaositai intrusion (recalculated from the data of Li et al. 2012a). Note that the zircon $\varepsilon_{\mathrm{Hf}}(t)$ values are plotted above the inferred evolution line of SCLM (figure 5). In addition to an enriched mantle component, a large amount of asthenospheric material is therefore needed to involve. Indeed, this inference is further confirmed by the low $\delta^{57} \mathrm{Fe}$ values (average $=0.12 \%$ ), which resembles the magma derived from a depleted mantle source (figure 6). Both of the Hf and Fe isotopic compositions give clear evidence for a large addition of asthenospheric material during the formation of the Gaositai (Late Triassic) intrusion.

\subsubsection{Early Cretaceous}

Zircon $\mathrm{U}-\mathrm{Pb}$ dating carried out in this study indicates an emplacement age of $\sim 140$ Ma for both the Longwangmiao and Heishan intrusions. As shown in figure 4(c), Late Mesozoic mafic-ultramafic magmatism is being reported for the first time in the Damiao and neighbouring areas.

These two intrusions are characterized by notably low zircon $\varepsilon_{\mathrm{Hf}}(t)$ values and old Hf model ages. On the $\varepsilon_{\mathrm{Hf}}(t)$ vs. age diagram (figure 5), they are both plotted below the inferred evolution line of SCLM. Although crustal contamination likely accounts for their Hf isotopic features, the restricted range of zircon $\varepsilon_{\mathrm{Hf}}(t)$ values implies that the parental magma should escape being intensely contaminated during ascent. Furthermore, these two intrusions clearly exhibit high $\delta^{57} \mathrm{Fe}$ values with averages of 0.34 and $0.35 \%$, respectively (figure 6). These $\mathrm{Fe}$ isotopic features further exclude an interpretation of the input of a continental crust component, and instead suggest that the Fe isotopic signal of the mantle source region was greatly changed by mantle metasomatism. Therefore, the parental magma of the Early Cretaceous intrusions should be produced by melting significantly-enriched mantle, which is isotopically distinct from the weakly-enriched SCLM that was predominant in the Paleozoic.

Contrasting source regions, as revealed by distinct isotopic ( $\mathrm{Hf}$ and $\mathrm{Fe}$ ) signals for different intrusions in the Damiao area, are consistent with their petrographic features. Only the Gaositai intrusion, the formation for which was largely involved with the asthenospheric mantle reservoir, displays the occurrence of dunite. Additionally, note that the tectonic position of Damiao during the evolution of the NCC has an important bearing on 
the recognization of multistage Phanerozoic maficultramafic magmatism in this area. As shown in figure 1(a), the Damiao area is located near the intersection of the northern margin of the NCC and the Daxing'anling-Taihangshan gravity lineament. Moreover, the Jining-Longhua fracture zone provides a beneficial emplacement condition for mantle-derived magma.

\subsection{Implications for lithospheric destruction in the northern $N C C$}

Lithospheric destruction of the NCC has been the subject of considerable geological interest over the last few decades. Although a broad consensus has been reached that the climax of the destruction of the NCC took place in the Late Mesozoic (e.g., Gao et al. 2004; Wu et al. 2005; Yang et al. 2008), there is no agreement when it comes to the initiation timing and duration (e.g., Wu et al. 2008; Xu et al. 2009; Zhu et al. 2012b). Much research suggests that the destruction of the NCC occurred over a long period of time, initiated in the Late Paleozoic (e.g., Xu et al. 2009; Li et al. 2009b; Zhou et al. 2012) or Early Mesozoic (e.g., Han et al. 2004; Yang et al. 2007a; Yang and Wu 2009; Zhang et al. 2012). Other research favours a short-timescale model, beginning from the Late Jurassic (e.g., Jiang et al. 2005).

Magmatically, lithospheric destruction is reflected successively by asthenospheric mantle upwelling, decompression-induced melting and subsequent strong involvement of a depleted component in magma generation. As described above, the $\sim 395 \mathrm{Ma}$ intrusions in the Damiao area were derived from the prevalent slightly-enriched SCLM beneath the northern NCC. In fact, the $465 \mathrm{Ma}$ Fuxian kimberlite and 280 Ma Guyang gabbro are similar cases (figure 5). However, both the $\mathrm{Hf}$ and Fe isotopic features lead to the conclusion that asthenospheric material was strongly involved in the generation of the $\sim 215$ Ma Gaositai intrusion, as well as the mafic enclaves from the Xiuyan granitoid, Liaodong peninsula. It is thus implied that lithospheric destruction in the northern NCC should have been initiated in Late Triassic time, earlier than in the interior part of the NCC (Late Mesozoic; Xu et al. 2009). Coincidentally, asthenospheric mantle upwelling and strong involvement of depleted component in mantle-derived magma just postdate the final closure of the Paleoasian Ocean ( 250 Ma; Xiao et al. 2003; Zhang et al. 2009c). Accordingly, lithospheric destruction in the northern NCC was probably caused by postorogenic extension following the collision between the Siberian Craton and the NCC. A reasonable inference is that the tectonic evolution of marginal orogenic belts around the craton may have played a key role in the widespread Late Mesozoic lithospheric destruction of the NCC (Xu 2004; Zhang et al. 2013).

As stated above, a significantly-enriched mantle component is identified beneath the northern NCC in addition to the prevalent SCLM. It was abruptly present as a magma source during Late Mesozoic time. Zircons from the $\sim 140 \mathrm{Ma}$ intrusions in the Damiao area record old Hf model ages of $\sim 1.5$ Ga. The lack of a coeval tectono-magmatic event in the northern NCC implies that the significantlyenriched mantle was refertilized by multistage mantle metasomatism, which may be related to the $\sim 1.85 \mathrm{Ga}$ collision between the eastern and western blocks and the continuous southward subduction of the Paleoasian Ocean (Tang et al. 2013). We interpret this isotopically enriched mantle reservoir as 'metasomes', which are commonly resided at depths of $\sim 100 \mathrm{~km}$ in the ancient cratonic lithospheric mantle (Waters and Erlank 1988; Xu 2001; Xu et al. 2009). They would not be melted until the lithosphere was thin enough and heat transfer was enhanced from the

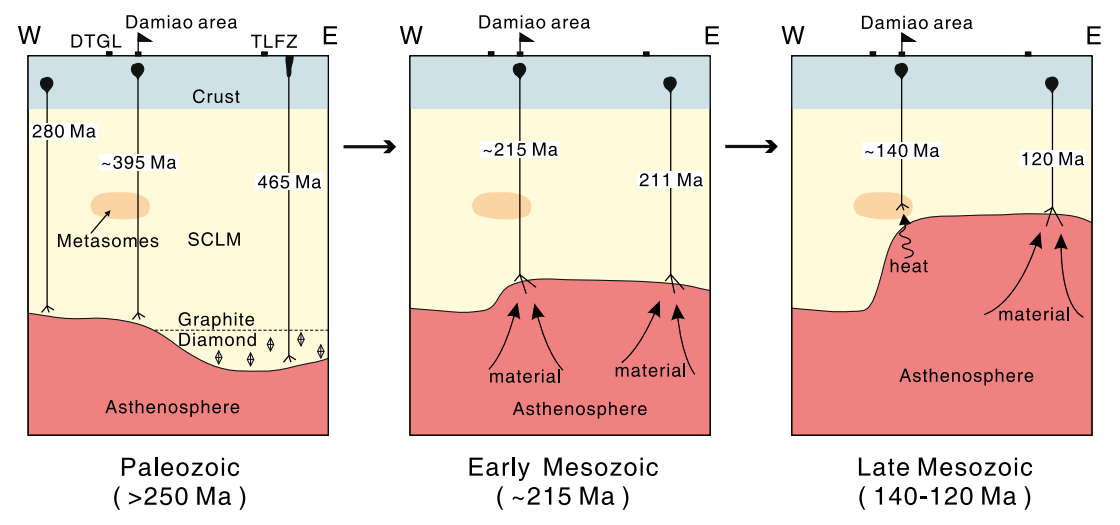

Figure 7. Cartoon illustrating the lithospheric destruction process beneath the northern NCC (c.f., Xu et al. 2009). SCLM: subcontinental lithospheric mantle; TLFZ: Tan-Lu fracture zone; DTGL: Daxing'anling-Taihangshan gravity lineament. 
asthenosphere. This explanation is further confirmed by the clearly high zircon $\varepsilon_{\mathrm{Hf}}(t)$ values of the mafic enclaves from the Gudaoling granitoid, Liaodong peninsula (figure 5). As illustrated in figure 1(a), this area is far from the Trans-North China Orogen and thus metasomatism of the cratonic lithospheric mantle is not as intense as in the Damiao area. As a result, 'metasomes' might not be present in the Liaodong peninsula and the Hf isotopic compositions of mantle-derived magma would be as depleted as the mafic enclaves from the Xiuyan granitoid and the Gaositai intrusion owing to the large involvement of asthenospheric material. In summary, isotopically distinct mantle sources of the mafic-ultramafic magmatism in the northern NCC can be interpreted as a record of mantle heterogeneity and the gradual upward migration of the lithosphere-asthenosphere boundary during lithospheric destruction (figure 7).

\section{Conclusions}

- Our newly-obtained zircon U-Pb ages, coupled with previous data, reveal that the emplacement ages of the mafic-ultramafic intrusions in the Damiao area span from Middle Devonian to Early Cretaceous times. As reflected by Hf-Fe isotope systematics, distinct mantle components contributed to their magma generation.

- The $\sim 395 \mathrm{Ma}$ intrusions were derived from the slightly-enriched SCLM that was prevalent during the Paleozoic, whereas asthenospheric material was strongly involved in the formation of the $\sim 215$ Ma Gaositai intrusion. This suggests that lithospheric destruction in the northern NCC would have been initiated in Late Triassic time, probably triggered by post-orogenic extension following the $\sim 250$ Ma collision between the Siberian Craton and the NCC.

- A significantly-enriched mantle component is identified in addition to the predominant slightly-enriched SCLM by the isotopic signals of $\sim 140$ Ma intrusions. It might have resided in the ancient cratonic lithospheric mantle, and would not have melted until the Late Mesozoic when the lithosphere was thin enough and heat transfer was enhanced from the asthenosphere during lithospheric destruction.

\section{Acknowledgements}

The authors are grateful to Changhou Zhang for his help in the field. Xiaoming Liu, Hong Zhang and Zhihong Li are much thanked for the laboratory assistances. The authors owe many thanks to two anonymous reviewers for their valuable comments and suggestions, as well as Prof. Ahmad for his editorial handling and review. This work was financially supported by the China Geological Survey Project (1212011220921 and 12120113094100).

\section{References}

Andersen T 2002 Correction of common lead in U-Pb analyses that do not report ${ }^{204} \mathrm{~Pb} ;$ Chem. Geol. $19259-$ 79.

Bai W J, Zhou M F, Hu X F, Cai Y C and Zheng X H 1993 Mafic-ultramafic magmatism and tectonic evolution of the North China Craton; Seismology Press, Beijing, 294p (in Chinese).

Blichert-Toft J and Albarède F 1997 The Lu-Hf isotope geochemistry of chondrites and the evolution of the mantle-crust system; Earth Planet Sci. Lett. 148 243-258.

Carlson R W, Pearson D G and James D E 2005 Physical, chemical, and chronological characteristics of continental mantle; Rev. Geophys. 43 RG1001.

Chen L, Cheng C and Wei Z G 2009a Seismic evidence for significant lateral variations in lithospheric thickness beneath the central and western North China Craton; Earth Planet Sci. Lett. 286 171-183.

Chen B, Suzuki K, Tian W, Jahn B M and Ireland T 2009b Geochemistry and Os-Nd-Sr isotopes of the Gaositai Alaskan-type ultramafic complex from the northern North China craton: Implications for mantle-crust interaction; Contrib. Mineral. Petrol. 158 683-702.

Chen L, Tao W, Zhao L and Zheng T Y 2008 Distinct lateral variation of lithospheric thickness in the northeastern North China Craton; Earth Planet Sci. Lett. 267 56-68.

Dauphas N, Craddock P R, Asimow P D, Bennett V C, Nutman A P and Ohnenstetter D 2009 Iron isotopes may reveal the redox conditions of mantle melting from Archean to Present; Earth Planet Sci. Lett. 288 255-267.

Dauphas N, Teng F Z and Arndt N T 2010 Magnesium and iron isotopes in $2.7 \mathrm{Ga}$ Alexo komatiites: Mantle signatures, no evidence for Soret diffusion, and identification of diffusive transport in zoned olivine; Geochim. Cosmochim. Acta $\mathbf{7 4}$ 3274-3291.

Dong G C, Santosh M, Li S R, Shen J F, Mo X X, Scott S, Qu K and Wang X 2013 Mesozoic magmatism and metallogenesis associated with the destruction of the North China Craton: Evidence from $\mathrm{U}-\mathrm{Pb}$ geochronology and stable isotope geochemistry of the Mujicun porphyry $\mathrm{Cu}$-Mo deposit; Ore Geol. Rev. 53 434-445.

Gao S, Rudnick R L, Yuan H L, Liu X M, Liu Y S, Xu W L, Ling W L, Ayers J, Wang X C and Wang Q H 2004 Recycling lower continental crust in the North China craton; Nature 432 892-897.

Griffin W L, Pearson N J, Belousova E, Jackson S E, Van Achterbergh E, O'Reilly S Y and Shee S R 2000 The Hf isotope composition of cratonic mantle: LAMMC-ICPMS analysis of zircon megacrysts in kimberlites; Geochim. Cosmochim. Acta 64 133-147.

Griffin W L, Powell W J, Pearson N J and O'Reilly S Y 2008 GLITTER: Data reduction software for laser ablation ICP-MS; In: Laser Ablation-ICP-MS in the Earth Sciences (ed.) Sylvester P, Mineralogical Association of Canada Short Course Series, pp. 204-207. 
Griffin W L, Wang X, Jackson S E, Pearson N J, O'Reilly S Y, Xu X S and Zhou X M 2002 Zircon chemistry and magma mixing, SE China: In-situ analysis of Hf isotopes, Tonglu and Pingtan igneous complexes; Lithos 61 $237-269$.

Han B F, Kagami H and Li H M 2004 Age and Nd-Sr isotopic geochemistry of the Guangtoushan alkaline granite, Hebei province, China: Implications for early Mesozoic crust-mantle interaction in North China block; Acta Petrol. Sinica 20 1375-1388 (in Chinese with English abstract).

Hebei Bureau of Geology and Mineral Resources (HBGMR) 1989 Regional geology of Hebei Province, Beijing Municipality and Tianjin Municipality; Geological Publishing House, Beijing, 741p (in Chinese).

Himmelberg G R and Loney R A 1995 Characteristics and petrogenesis of Alaskan-type ultramafic-mafic intrusions, southeastern Alaska; US Geol. Surv. Prof. Paper 1564 $1-47$.

Huang F, Zhang Z F, Lundstrom C C and Zhi X C 2011 Iron and magnesium isotopic compositions of peridotite xenoliths from eastern China; Geochim. Cosmochim. Acta 75 3318-3334.

Jiang Y H, Jiang S Y, Zhao K D, Ni P, Ling H F and Liu D Y 2005 SHRIMP U-Pb zircon dating for lamprophyre from Liaodong Peninsula: Constraints on the initial time of Mesozoic lithosphere thinning beneath eastern China; Chinese Sci. Bull. 50 2612-2620.

Kwon S, Kim S W and Santosh M 2013 Multiple generations of mafic-ultramafic rocks from the Hongseong suture zone, western South Korea: Implications for the geodynamic evolution of NE Asia; Lithos 160 6883.

Li H M, Wang R J, Xiao K Y, Zhang X H, Liu Y L and Sun L 2009a Characteristics and current utilization status of ultra-low-grade magnetite resource, and suggestion on its exploration and development; Geol. Bull. China 28 8590 (in Chinese with English abstract).

Li H Y, Xu Y G, Huang X L, He B, Luo Z Y and Yan B 2009b Activation of northern margin of the North China Craton in Late Paleozoic: Evidence from $\mathrm{U}-\mathrm{Pb}$ dating and $\mathrm{Hf}$ isotopes of detrital zircons from the Upper Carboniferous Taiyuan Formation in the Ningwu-Jingle basin; Chinese Sci. Bull. 54 677-686.

Li L X, Li H M, Cui Y H, Zhu M Y, Wang D Z, Yang X Q, Liu M J and Chen J 2012a Geochronology and petrogenesis of the Gaositai Cr-bearing ultramafic complex, Hebei Province, China; Acta Petrol. Sinica 28 3757-3771 (in Chinese with English abstract).

Li L X, Li H M, Wang D Z, Liu M J, Yang X Q and Chen J 2012b Ore genesis and ore-forming age of the Tiemahabaqin ultra-low-grade iron deposit in Chengde, Hebei Province, China; Rock Miner. Anal. 31 898-905 (in Chinese with English abstract).

Li S R and Santosh M 2013 Metallogeny and craton destruction: Records from the North China Craton; Ore Geol. Rev., doi: 10.1016/j.oregeorev.2013.03.002.

Ling M X, Li Y, Ding X, Teng F Z, Yang X Y, Fan W M, Xu Y G and Sun W D 2013 Destruction of the North China Craton induced by ridge subductions; J. Geol. 121 $197-213$.

Liu X M, Gao S, Diwu C R, Yuan H L and Hu Z C 2007 Simultaneous in-situ determination of $\mathrm{U}-\mathrm{Pb}$ age and trace elements in zircon by LA-ICP-MS in $20 \mu \mathrm{m}$ spot size; Chinese Sci. Bull. 52 1257-1264.

Ludwig K R 2003 User's manual for Isoplot 3.00: A geochronological toolkit for Microsoft Excel; Berkeley Geochronology Center, California, 67p.
Luo Z H, Yang Z F, Dai G, Cheng L L and Zhou J L 2013 Crystal populations of igneous rocks and their implications in genetic mineralogy; Geol. China 40 176-181 (in Chinese with English abstract).

Ma X, Chen B, Chen J F and Niu X L 2013 Zircon SHRIMP U-Pb age, geochemical, $\mathrm{Sr}-\mathrm{Nd}$ isotopic, and $\mathrm{in}$ situ Hf isotopic data of the Late Carboniferous-Early Permian plutons in the northern margin of the North China Craton; Sci. China Ser. D 56 126-144.

Malitch K N, Belousova E A, Griffin W L, Badanina I Y, Pearson N J, Presnyakov S L and Tuganova E V 2010 Magmatic evolution of the ultramafic-mafic Kharaelakh intrusion (Siberian Craton, Russia): Insights from traceelement, U-Pb and Hf-isotope data on zircon; Contrib. Mineral. Petrol. 159 753-768.

Menzies M A, Fan W M and Zhang M 1993 Palaeozoic and Cenozoic lithoprobes and the loss of $>120 \mathrm{~km}$ of Archaean lithosphere, Sino-Korean craton, China; In: Magmatic Processes and Plate Tectonics (eds) Prichard H M, Alabaster T, Harris N B W and Neary C R; Geol. Soc. Spec. Publ., pp. 71-81.

Pettigrew N T and Hattori K H 2006 The Quetico intrusions of western Superior Province: Neo-Archean examples of Alaskan/Ural-type mafic-ultramafic intrusions; Precamb. Res. 149 21-42.

Poitrasson F 2006 On the iron isotope homogeneity level of the continental crust; Chem. Geol. 235 195-200.

Poitrasson F, Delpech G and Grégoire M 2013 On the iron isotope heterogeneity of lithospheric mantle xenoliths: Implications for mantle metasomatism, the origin of basalts and the iron isotope composition of the Earth; Contrib. Mineral. Petrol. 165 1243-1258.

Söderlund U, Patchett P J, Vervoort J D and Isachsen C E 2004 The ${ }^{176} \mathrm{Lu}$ decay constant determined by $\mathrm{Lu}-\mathrm{Hf}$ and $\mathrm{U}-\mathrm{Pb}$ isotope systematics of Precambrian mafic intrusions; Earth Planet. Sci. Lett. 219 311-324.

Su B X, Qin K Z, Sakyi P A, Li X H, Yang Y H, Sun H, Tang D M, Liu P P, Xiao Q H and Malaviarachchi S P K $2011 \mathrm{U}-\mathrm{Pb}$ ages and $\mathrm{Hf}-\mathrm{O}$ isotopes of zircons from Late Paleozoic mafic--ultramafic units in the southern Central Asian Orogenic Belt: Tectonic implications and evidence for an Early-Permian mantle plume; Gondwana Res. 20 $516-531$.

Su S G and Lesher C M 2012 Genesis of PGE mineralization in the Wengeqi mafic-ultramafic complex, Guyang County, Inner Mongolia, China; Miner. Deposita $\mathbf{4 7}$ 197-207.

Tang S H, Zhu X K, Cai J J, Li S Z, He X X and Wang J H 2006 Chromatographic separation of $\mathrm{Cu}$, Fe and $\mathrm{Zn}$ using AGMP-1 anion exchange resin for isotope determination by MC-ICPMS; Rock Miner. Anal. 25 5-8 (in Chinese with English abstract).

Tang Y J, Zhang H F, Ying J F, Su B X, Chu Z Y, Xiao Y and Zhao X M 2013 Highly heterogeneous lithospheric mantle beneath the central zone of the North China Craton evolved from Archean mantle through diverse melt refertilization; Gondwana Res. 23 130-140.

Taylor H P Jr and Noble J A 1969 Origin of magnetite in the zoned ultramafic complexes of southeastern Alaska; In: Magmatic Ore Deposits (ed.) Wilson H D B, Econ. Geol. Monographs, pp. 209-230.

Teng F Z, Dauphas N, Huang S C and Marty B 2013 Iron isotopic systematics of oceanic basalts; Geochim. Cosmochim. Acta 107 12-26.

Tian W, Chen B, Liu C Q and Zhang H F 2007 Zircon U-Pb age and Hf isotopic composition of the Xiaozhangjiakou ultramaric pluton in northern Hebei; Acta Petrol. Sinica 23 583-590 (in Chinese with English abstract). 
Tian Y, Zhao D P, Sun R M and Teng J W 2009 Seismic imaging of the crust and upper mantle beneath the North China Craton; Phys. Earth. Planet. Inter. 172 169-182.

Trap P, Faure M, Lin W, Augier R and Fouassier A 2011 Syn-collisional channel flow and exhumation of Paleoproterozoic high pressure rocks in the Trans-North China Orogen: The critical role of partial-melting and orogenic bending; Gondwana Res. 20 498-515.

Tseng C Y, Zuo G C, Yang H J, Yang H Y, Tung K A, Liu D Y and Wu H Q 2009 Occurrence of Alaskantype mafic-ultramafic intrusions in the North Qilian Mountains, northwest China: Evidence of Cambrian arc magmatism on the Qilian Block; Isl. Arc 18 526-549.

Wang F, Chen F K, Siebel W, Li S Q, Peng P and Zhai M G 2011 Zircon U-Pb geochronology and Hf isotopic composition of the Hongqiyingzi Complex, northern Hebei Province: New evidence for Paleoproterozoic and late Paleozoic evolution of the northern margin of the North China craton; Gondwana Res. 20 122-136.

Waters F G and Erlank A J 1988 Assessment of the vertical extent and distribution of mantle metasomatism below Kimberley, South Africa; J. Petrol. Spec. Vol., pp. 185-204.

Weyer S and Ionov D A 2007 Partial melting and melt percolation in the mantle: The message from Fe isotopes; Earth Planet Sci. Lett. 259 119-133.

Wu F Y, Lin J Q, Wilde S A, Zhang X O and Yang J H 2005 Nature and significance of the Early Cretaceous giant igneous event in eastern China; Earth Planet Sci. Lett. 233 103-119.

Wu F Y, Xu Y G, Gao S and Zheng J P 2008 Lithospheric thinning and destruction of the North China Craton; Acta Petrol. Sinica 24 1145-1174 (in Chinese with English abstract).

Xiao W J, Windley B F, Hao J and Zhai M G 2003 Accretion leading to collision and the Permian Solonker suture, Inner Mongolia, China: Termination of the central Asian orogenic belt; Tectonics 221069.

Xie C X, Li H M, Wang R J and Xiao K Y 2009 Analysis of the quantity and distribution of the total identified iron resources in China and their supply capability; Acta Geosci. Sinica 30 387-394 (in Chinese with English abstract).

Xie C X, Zhang X H, Wang S B, Xiao K Y and Li H M 2006 Characteristics of the extremely poor vanadotitanomagnetite deposit in Chengde City, Hebei Province; Mineral Deposit 25 487-490 (in Chinese).

Xie G H 2005 The petrology and geochemistry of Damiao massif-anorthosite and Miyun rapakivi-granite: Involving discussion on distribution and significance of global massif-anorthosite and rapakivi granite; Science Press, Beijing. 195p (in Chinese).

Xu W L, Zhou Q J, Pei F P, Yang D B, Gao S, Li Q L and Yang Y H 2013 Destruction of the North China Craton: Delamination or thermal/chemical erosion? Mineral chemistry and oxygen isotope insights from websterite xenoliths; Gondwana Res. 23 119-129.

Xu Y G 2001 Thermo-tectonic destruction of the Archaean lithospheric keel beneath the Sino-Korean Craton in China: Evidence, timing and mechanism; Phys. Chem. Earth A 26 747-757.

Xu Y G 2004 Lithospheric thinning beneath North China: A temporal and spatial perspective; Geol. J. China Univ. 10 324-331 (in Chinese with English abstract).

Xu Y G 2007 Diachronous lithospheric thinning of the North China Craton and formation of the Daxin'anlingTaihangshan gravity lineament; Lithos 96 281-298.

Xu Y G, Li H Y, Pang C J and He B 2009 On the timing and duration of the destruction of the North China Craton; Chinese Sci. Bull. 54 3379-3396.
Yan Y, Hu X Q, Lin G, Liu W L and Song Z J 2010 Detrital zircon and apatite fission track data in the Liaoxi basins: Implication to Meso-Cenozoic thermo-tectonic evolution of the northern margin of the North China Craton; J. Earth Syst. Sci 119 541-551.

Yang J H and Wu F Y 2009 Triassic magmatism and its relation to decratonization in the eastern North China Craton; Sci. China Ser D 52 1319-1330.

Yang J H, Wu F Y, Liu X M and Xie L W 2005 Zircon U$\mathrm{Pb}$ ages and $\mathrm{Hf}$ isotopes and their geological significance of the Miyun rapakivi granites from Beijing, China; Acta Petrol. Sinica 21 1633-1644 (in Chinese with English abstract).

Yang J H, Wu F Y, Wilde S A, Belousova E and Griffin W L 2008 Mesozoic decratonization of the North China block; Geology 36 467-470.

Yang J H, Wu F Y, Wilde S A and Liu X M 2007a Petrogenesis of Late Triassic granitoids and their enclaves with implications for post-collisional lithospheric thinning of the Liaodong Peninsula, North China Craton; Chem. Geol. 242 155-175.

Yang J H, Wu F Y, Wilde S A, Xie L W, Yang Y H and Liu X M 2007b Tracing magma mixing in granite genesis: In situ $\mathrm{U}-\mathrm{Pb}$ dating and Hf-isotope analysis of zircons; Contrib. Mineral. Petrol. 153 177-190.

Yang Y H, Liu S, Hu R Z, Feng C X, Feng G Y, Yang C G and Qi Y Q 2012 Geochemistry and petrogenesis of the Sanchakou mafic dyke in Chengde, Hebei Province, China; J. Jilin Univ. 42 1796-1805 (in Chinese with English abstract).

Yuan H L, Gao S, Dai M N, Zong C L, Günther D, Fontaine G H, Liu X M and Diwu C R 2008 Simultaneous determinations of $\mathrm{U}-\mathrm{Pb}$ age, $\mathrm{Hf}$ isotopes and trace element compositions of zircon by excimer laser-ablation quadrupole and multiple-collector ICP-MS; Chem. Geol. 247 100-118.

Zhang H F, Sun M, Zhou X H, Fan W M, Zhai M G and Yin J F 2002 Mesozoic lithosphere destruction beneath the North China Craton: Evidence from major-, traceelement and $\mathrm{Sr}-\mathrm{Nd}-\mathrm{Pb}$ isotope studies of Fangcheng basalts; Contrib. Mineral. Petrol. 144 241-254.

Zhang H F and Yang Y H 2007 Emplacement age and $\mathrm{Sr}-\mathrm{Nd}-\mathrm{Hf}$ isotopic characteristics of the diamondiferous kimberlites from the eastern North China Craton; Acta Petrol. Sinica 23 285-294 (in Chinese with English abstract).

Zhang H F, Zhu R X, Santosh M, Ying J F, Su B X and Hu Y 2013 Episodic widespread magma underplating beneath the North China Craton in the Phanerozoic: Implications for craton destruction; Gondwana Res. 23 95-107.

Zhang K J 2012 Destruction of the North China Craton: Lithosphere folding-induced removal of lithospheric mantle? J. Geodyn. 53 8-17.

Zhang S H, Liu S W, Zhao Y, Yang J H, Song B and Liu X M 2007 The 1.75-1.68 Ga anorthosite-mangerite-alkali granitoid-rapakivi granite suite from the northern North China Craton: Magmatism related to a Paleoproterozoic orogen; Precamb. Res. 155 287-312.

Zhang S H, Zhao Y, Liu X C, Liu D Y, Chen F K, Xie L W and Chen H H 2009a Late Paleozoic to Early Mesozoic mafic-ultramafic complexes from the northern North China Block: Constraints on the composition and evolution of the lithospheric mantle; Lithos 110 229-246.

Zhang S H, Zhao Y, Kröner A, Liu X M, Xie L W and Chen F K 2009b Early Permian plutons from the northern North China Block: Constraints on continental arc evolution and convergent margin magmatism related to the Central Asian Orogenic Belt; Int. J. Earth. Sci 98 1441-1467.

Zhang S H, Zhao Y, Song B, Hu J M, Liu S W, Yang Y H, Chen F K, Liu X M and Liu J 2009c Contrasting 
Late Carboniferous and Late Permian-Middle Triassic intrusive suites from the northern margin of the North China craton. Geochronology, petrogenesis, and tectonic implications; Geol. Soc. Am. Bull. 121 181-200.

Zhang S H, Zhao Y, Ye H, Hou K J and Li C F 2012 Early Mesozoic alkaline complexes in the northern North China Craton: Implications for cratonic lithospheric destruction; Lithos 155 1-18.

Zhang X H, Mao Q, Zhang H F, Zhai M G, Yang Y H and $\mathrm{Hu}$ Z C 2011 Mafic and felsic magma interaction during the construction of high-K calc-alkaline plutons within a metacratonic passive margin: The Early Permian Guyang batholith from the northern North China Craton; Lithos 125 569-591.

Zhao T P, Chen W and Zhou M F 2009 Geochemical and $\mathrm{Nd}-\mathrm{Hf}$ isotopic constraints on the origin of the $\sim 1.74 \mathrm{Ga}$ Damiao anorthosite complex, North China Craton; Lithos 113 673-690.

Zhao X M, Zhang H F, Zhu X K, Tang S H and Tang Y J 2010 Iron isotope variations in spinel peridotite xenoliths from North China Craton: Implications for mantle metasomatism; Contrib. Mineral. Petrol. 160 1-14.
Zhao X M, Zhang H F, Zhu X K, Tang S H and Yan B 2012 Iron isotope evidence for multistage melt-peridotite interactions in the lithospheric mantle of eastern China; Chem. Geol. 292 127-139.

Zheng Y F, Xiao W J and Zhao G C 2013 Introduction to tectonics of China; Gondwana Res. 23 1189-1206.

Zhou J L, Luo Z H, He H Y and Sun J 2012 New ${ }^{40} \mathrm{Ar} /{ }^{39} \mathrm{Ar}$ geochronologic constraint on the age of Damiao $\mathrm{Fe}-\mathrm{Ti}-$ $\mathrm{P}$ deposits, North China Craton and its geological significance; Earth Sci. Front. 19 110-117 (in Chinese with English abstract).

Zhu G, Jiang D Z, Zhang B L and Chen Y 2012a Destruction of the eastern North China Craton in a backarc setting: Evidence from crustal deformation kinematics; Gondwana Res. 22 86-103.

Zhu R X, Yang J H and Wu F Y 2012b Timing of destruction of the North China Craton; Lithos 149 51-60.

Zhu X K, Li Z H, Zhao X M, Tang S H, He X X and Belshaw N S 2008 High-precision measurements of Fe isotopes using MC-ICP-MS and Fe isotope compositions of geological reference materials; Acta Petrol. Mineral. 27 263-272. (in Chinese with English abstract). 